\title{
Horizontal Distribution of the Zooplankton in Devils Lake, North Dakota.
}

\author{
By k. G. Moberg, University of North Dakota.
}

With 2 maps in text.

II.

Series D. This series was collected on June 21, 1915, well out in the main part of the lake as shown on the map. A very slight south-west wind was blowing and the sky was clear. The time required was about one hour and the distances between each two points about 200 meters. Table VII shows the results.

Table VII.

Showing results of analyses of samples of Series D.

\begin{tabular}{|c|c|c|c|c|c|c|c|c|c|}
\hline \multirow[t]{2}{*}{ Point .... } & \multicolumn{2}{|l|}{1} & \multicolumn{2}{|c|}{ 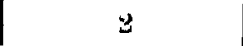 } & \multicolumn{2}{|c|}{3} & \multicolumn{2}{|c|}{4} & \multirow[b]{2}{*}{ 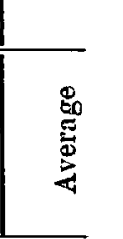 } \\
\hline & 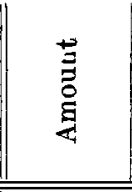 & 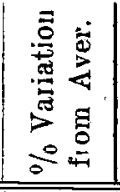 & $\begin{array}{l}\text { 泀 } \\
\text { 豈 }\end{array}$ & 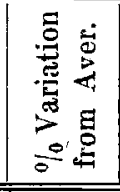 & $\begin{array}{l}\text { 节 } \\
\text { ğ }\end{array}$ & 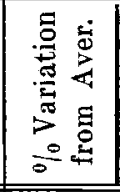 & $\begin{array}{l}\text { 音 } \\
\text { 旁 }\end{array}$ & 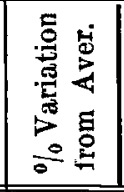 & \\
\hline Deptl & 5.7 & $+\quad 1.4$ & 5.7 & $+\quad 1.4$ & 5.6 & $-\quad 0.4$ & 5,5 & -2.1 & 562 \\
\hline Temperature & 20.0 & $\begin{array}{ll}- & 0.7\end{array}$ & 20.0 & -0.7 & 20.3 & $+\quad 0.7$ & 20.3 & $\dashv \quad 0,7$ & 20.15 \\
\hline nia .... & 0.20 & +90.4 & 010 & $-\quad 4.7$ & 0.06 & 42.7 & 0.06 & $-\quad 42.7$ & 0.103 \\
\hline $\begin{array}{l}\text { Alb. Ammo- } \\
\text { nia ... }\end{array}$ & 0.94 & +7.8 & 0.91 & +4. & 080 & 8.2 & 0.81 & 3.6 & 0.872 \\
\hline Oxygen ... & 6.46 & $\begin{array}{cc}+ & 0.4\end{array}$ & 6.27 & - 2.3 & 655 & $+\quad 1.8$ & $\therefore$ & - & 6.43 \\
\hline Alkalinity. & 824.0 & $+\quad 0.9$ & 811.0 & 0.6 & 814.0 & 0.3 & -- & - & 816.0 \\
\hline Amorphous. & $2,(150,000$ & +22.5 & $1,550.000$ & - & $1,850,000$ & ) +10.6 & $1,240,000$ & $\ldots \quad 258$ & $1,672,500$ \\
\hline Micrococcus & $8,420,000$ & $-\quad 5.6$ & $9,280,000$ & + & $8,000,000$ & -103 & $10,000,000$ & -120 & $8,425,000$ \\
\hline Nodularia. & 4,400 & -31.7 & 10,400 & $0+61.2$ & $9,2 \div 0$ & $-\frac{1}{-} \quad 42.6$ & $1,80 n$ & 721 & 6,450 \\
\hline Other Algae & 152,000 & $-\quad 3.2$ & 192,000 & $0+22.3$ & 150,000 & $-\quad 4.4$ & 134,000 & -14.6 & $157,001)$ \\
\hline B. satanicus & 16 & -84.1 & & -93.1 & & -1000 & 380 & $\mid-2762$ & 101 \\
\hline B. mulleri . & 24 & +118.1 & & -63.6 & & 1000 & 16 & $+\quad 45.4$ & 11 \\
\hline Pedilion : . & 60 & -14.3 & 96 & j- $\quad 37.1$ & & -100.0 & 124 & $1+77.1$ & 70 \\
\hline Cyclops... & & -100.0 & & -100.0 & 12 & +200.0 & 4 & 0 . & 4 \\
\hline Diaptomus & 16 & +300.0 & 0 & -100.0 & & -100.0 & 0 & -100.0 & 4 \\
\hline Naup:ii . . & 20 & 0 & 40 & $0 ; 1000$ & & -80.0 & 16 & $|-20.0|$ & 20 \\
\hline
\end{tabular}




\begin{tabular}{|c|c|c|}
\hline & 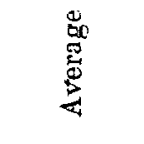 & 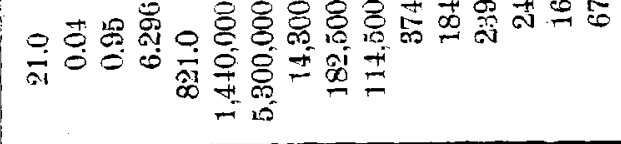 \\
\hline \multirow[b]{2}{*}{$H$} & 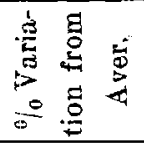 & 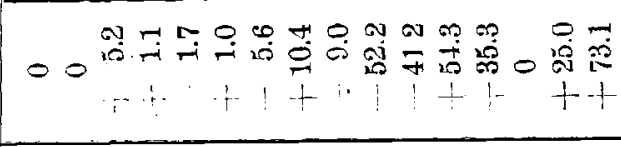 \\
\hline & $\stackrel{\stackrel{\Xi}{\Xi}}{\stackrel{\Xi}{\Xi}}$ & 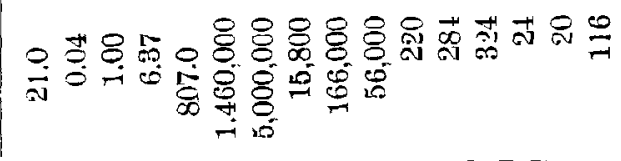 \\
\hline \multirow{2}{*}{$\infty$} & 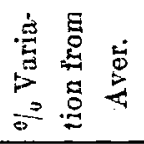 & 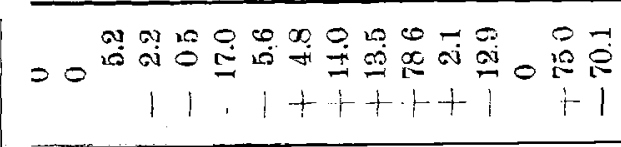 \\
\hline & 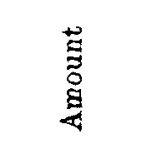 & 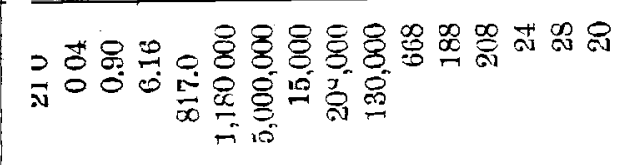 \\
\hline & 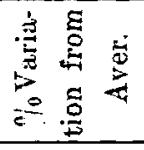 & 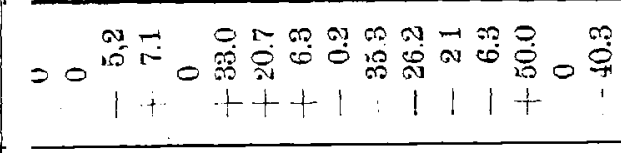 \\
\hline - & 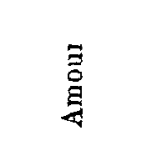 & 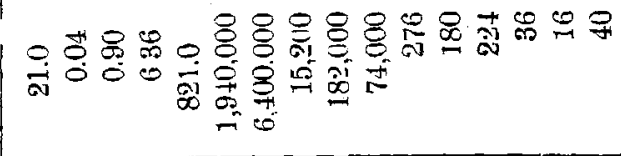 \\
\hline & 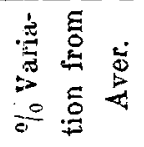 & 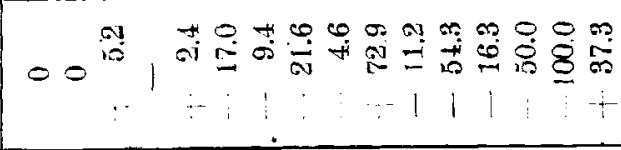 \\
\hline$r$ & 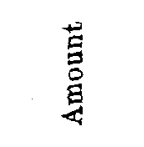 & 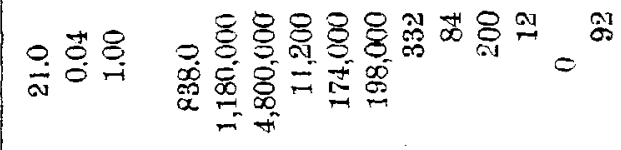 \\
\hline 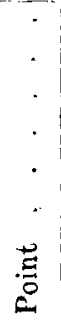 & & 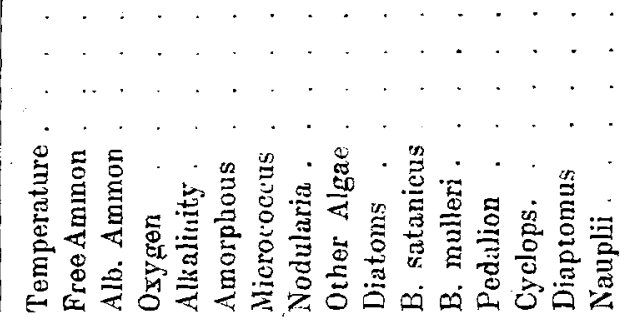 \\
\hline
\end{tabular}


Horizontal Distribution of the Zooplankton in Derils Lake, North Dakato. 291

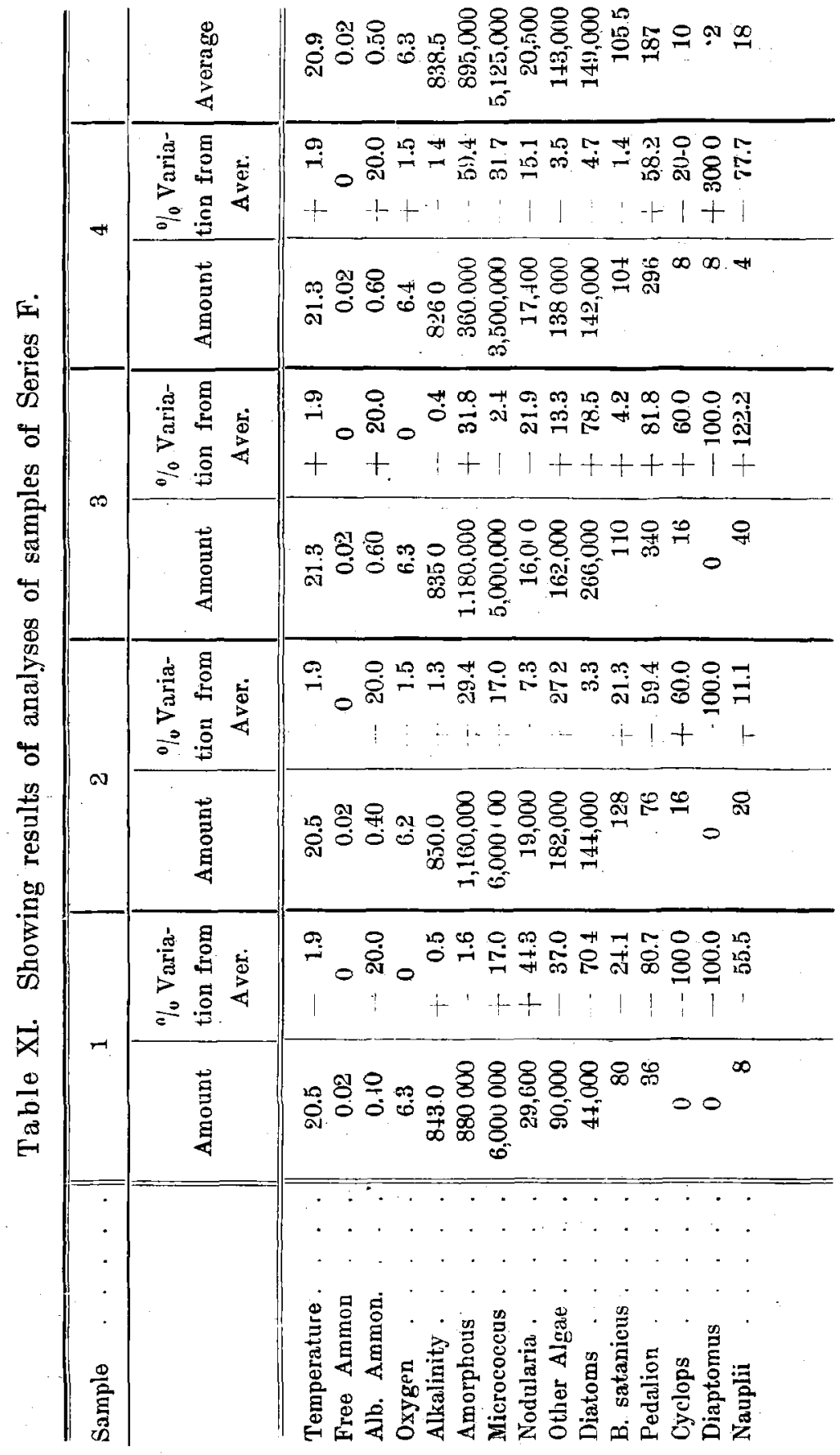


These analyses show a uniformity of physical and chemical conditions, except in the case of free ammonia which varies to an unusual extent. Since it is present in small amounts it is probable, however, that the greater part of the variation is due to experimental error. No relation is shown between the amount of ammonia and the amount of plankton. All the animals and especially the adult crustaceans occur in small numbers, so that some of them will be excluded in tabulating the variation percentages. It is important to note that at point 3 all the animals, except Cyclops and the Nauplii. are absent, while at point 4 most of them are quite numerous. The summary of the variations is shown in the following table:

Table VIJI. Percent of variation from average of Series D.

\begin{tabular}{|c|c|c|c|c|}
\hline & Mean & Maximum & Minimum & Range \\
\hline Amorphous & 14.5 & t- $\quad 22.5$ & 25.8 & 48.3 \\
\hline Micrococcus & : 79 & -12.0 & 103 & 22.3 \\
\hline Nodularia & -51.9 & $-\quad j-61,2$ & 722 & 183.8 \\
\hline Other Algae. . . . & 11.1 & | 22.3 & 14.6 & 369 \\
\hline B. satanicus......... & $\rightarrow \quad 138.1$ & 376.2 & 1000 & 376.2 \\
\hline I'edalion ............ & $\therefore \quad 55.7$ & +77.1 & 1000 & 177.1 \\
\hline Nauplii . . . . . . . . & 50.0 & 100.0 & 800 & 180.0 \\
\hline
\end{tabular}

Series E. This series was collected on July 27, 1915, from an anchored raft some distance from the shore, where the depth was about four meters. The four samples were taken at fifteen minute intervals beginning at 11:30 A. M. and continuing until 12:15 P. M. The wind was blowing from the south causing small waves, which increased in size toward the end of the series. Cloudiness and sunshine alternated at short intervals throughout the period. The results of the analyses are shown in Table IX (see p. 290).

Table X. Percent of variation from average of Series E.

\begin{tabular}{|c|c|c|c|c|}
\hline & Mean & Maximum & Minimum & Range \\
\hline Amorphous & $+17,0$ & -33.0 & -17.0 & 50.0 \\
\hline Micrococcus . . . & \pm 10.3 & +20.7 & - 9.4 & 30.1 \\
\hline Nodularia & \pm 10.8 & +10.4 & -21.6 & 32.0 \\
\hline Other Algate . . . . . . & \pm 6.9 & $T 14.0$ & -90 & 23.0 \\
\hline Diattoms . . . . . . & +43.5 & +72.9 & 52,2 & 125.1 \\
\hline B. satauicus. . & i 39.3 & 78.6 & -41.2 & 119.8 \\
\hline B mulleri $\ldots \ldots \ldots$ & +282 & +54.3 & $-\overline{0} 4.3$ & 118.6 \\
\hline$\ldots \ldots$ & +17.7 & ; 35.5 & 16.3 & 51.8 \\
\hline$\ldots \ldots$ & +25.0 & +50.0 & -50.0 & 1000 \\
\hline Diaptumus . . . . . . . . & 50.0 & +75.0 & 100.0 & 175.0 \\
\hline Nauplii . . . . . . . . & +55.2 & $+78,1$ & -70.1 & 143.4 \\
\hline
\end{tabular}


The temperature and the chemicals are almost constant. The first sample shows a small amount of animals while in sample 4 the zooplanktonts are abundant. The following table gives the summaly of the percentages (see p. 29 ).

Series F and G. These two series wero collected on August 3, 1915 , at the same point as was Series E. Series F represents samples taken from the surface, while the samples of Series G were taken from a depth of three meters. The samples of the two series were taken alternatingly at fifteen minute intervals, the period between the collecting of two samples of the same series therefore being a half hour. The first collection was made at 2:00 P. M. The sky was clear and there was almost no wind. The results of the analyses of Series F are shown in Table XI (see p. 291).

The analyses show the physical and and ehemical factors to be quite constant, and the total amount of plankton seems fairly evenly distributed except in 1 where all the animals and most of the plants are absent or few in number. The results are summarized in the following table.

T'able XII. Percent of variation from average of Series F.

\begin{tabular}{|c|c|c|c|c|}
\hline & Mean & Maximum & Minimum & Rangt \\
\hline Amorphous & \pm 30.5 & -31.8 & 59.4 & 91.2 \\
\hline Micrococcus ......... & \pm 17.0 & 广. 17.0 & -31.7 & 48.7 \\
\hline Nodularia & \pm 22.1 & +44.3 & $-\quad 21.9$ & 66.2 \\
\hline Other Algar. . & \pm 20.2 & 7. 27.2 & -37.0 & 64.2 \\
\hline Diatoms ........ & \pm 39.2 & +78.5 & -70.4 & 148.9 \\
\hline B. satanicus. . . . . . & \pm 12.7 & -21.3 & --24.1 & 45.4 \\
\hline Pedalion . . . . . . . & \pm 70.0 & +81.8 & -80.7 & 162.5 \\
\hline Cyclops $\ldots \ldots \ldots \ldots$ & $-\underline{6} 600$ & $-60,0$ & -100.0 & 160.0 \\
\hline Naupli . . . . . . . . . & $\pm 66.6^{\prime}$ & +122.2 & $\cdots 77.7$ & $199 . !$ \\
\hline
\end{tabular}

Table XIII shows the results of the analyses of Series G. Here the total amount of plankton appears to vary quite considerably since the different specirs show a parallel distribution. The chemicals are quite constant. A summary of the distribution of the different plankton forms are shown in the following table (see p. 294): 
Table XIIl. Showing results of analyses of samples of Series G.

\begin{tabular}{|c|c|c|c|c|c|c|c|c|c|}
\hline \multirow[t]{2}{*}{ Sample ... } & \multicolumn{2}{|c|}{1} & \multicolumn{2}{|c|}{2} & \multicolumn{2}{|c|}{3} & \multicolumn{2}{|c|}{4} & \multirow[b]{2}{*}{ 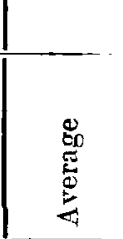 } \\
\hline & 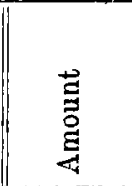 & 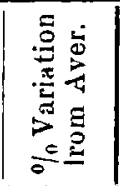 & . & 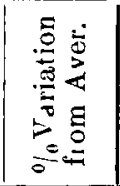 & $\begin{array}{l}\text { 菏 } \\
\text { 至 }\end{array}$ & 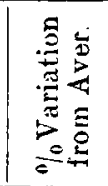 & $\begin{array}{l}\vec{\Xi} \\
\vec{\Xi} \\
\text { 茪 }\end{array}$ & 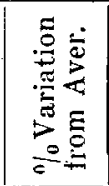 & \\
\hline iture & 20.0 & . & 200 & 0 & 200 & 0 & 20.0 & 0 & 20.0 \\
\hline nmon. & 0,02 & 0 & 002 & 0 & 0.02 & 0 & 0.02 & 0 & 0.02 \\
\hline non. & 0.40 & -20.0 & 040 & -20.0 & 060 & +20.0 & 0.60 & +20.0 & 0.50 \\
\hline Oxygt & 6.0 & 20 & 6.2 & $+\quad 1.1$ & 6.2 & $\because \quad 1.1$ & 0.1 & -03 & $6.12 ;$ \\
\hline it & 8270 & $-\quad 14$ & $8 \geq 9.0$ & 1.2 & 8340 & 0.6 & 868.0 & 33 & 839.5 \\
\hline us & 800,000 & -130 & 1.220 .000 & $7-31,1$ & 1080,000 & -16.1 & 620010 & -333 & 930,00 \\
\hline icrococcus. & $2,600,000$ & -37.7 & $4,300,000$ & $\begin{array}{r}1 \\
+\quad 2.0\end{array}$ & $t, 0 \cup 0,000$ & -4.1 & $5,800,000$ & +389 & $4,175,000$ \\
\hline fodularia.. & $.7,810$ & $+\quad 2.6$ & 11,400 & -500 & 4,000 & -173 & 7,200 & -5.3 & 7,60 \\
\hline Other Algae. & 104,000 & $\therefore \quad 47.7$ & $342.0 \vee 0$ & +74.4 & 172000 & -124 & 168,000 & -14.3 & 196,50 \\
\hline Diato & 132,000 & $\therefore \quad 102$ & $20+.000$ & $f-397$ & $3 \grave{j, 000}$ & -75.5 & 216,000 & 46.9 & 147,000 \\
\hline & 1,652 & +25.4 & 1,944 & $\begin{array}{l}+ \\
+\end{array}$ & 493 & -62.4 & 1,772 & -9.3 & $1,315,2$ \\
\hline & 28 & $\mid-\quad 71.5$ & 236 & +153.2 & 13 & -86.0 & 96 & +5.0 & 93.2 \\
\hline & 52 & $-\quad 43.3$ & & $+\quad 4.6$ & 67 & -26.9 & 152 & +65.6 & 91. \\
\hline Diaptomus & 32 & +100.0 & & $\left|\begin{array}{ll}1 & 50.0\end{array}\right|$ & 8 & -50.0 & 16 & 0 & 16 \\
\hline Nauplii & 72 & $|-\quad 34.5|$ & 164 & $\mid+490$ & & -92.7 & 196 & $\mid+78.1$ & 110 \\
\hline
\end{tabular}

Table XIV. Percent of variation from average of Series G.

\begin{tabular}{|c|c|c|c|c|}
\hline & Mean & Maximum & Miıimum & Range \\
\hline Amorplous & $\pm 23.6^{\circ}$ & +31.1 & -33.3 & 64.4 \\
\hline Mierococcus . . . . . . & \pm 20.9 & $-+\quad 38.9$ & -37.7 & 76.6 \\
\hline Nodularia & \pm 26.3 & $-t 50.0$ & -473 & $9 \overline{7} .3$ \\
\hline Other Algae. . . . . . . & \pm 372 & +74.4 & -47.7 & 122.1 \\
\hline Diatoms ......... & \pm+2.8 & +46.9 & -755 & $12 \cdot 2.4$ \\
\hline B. satanicus . . . . . & \pm 36.2 & t. 473 & $\cdots 62 n 9$ & 110.2 \\
\hline Pedalion .......... & \pm 786 & $+153 \cdot 2$ & -860 & 239.2 \\
\hline$\ldots \ldots$ & \pm 35.1 & +65.6 & -43.3 & 1089 \\
\hline Diaptomus . . . . . . . & \pm 50.0 & +100.0 & -511.0 & 1000 \\
\hline Nauplii . . . . . . . . . & $\pm t 3.6$ & $\dashv \quad 78.1$ & --92.7 & 170.8 \\
\hline
\end{tabular}

Series H. Since in the previous collections comparatively fow cru-taceans had been obtainel, it was decided to collect larger samples. On October 15, 1915, four large samples were therefore collected from approximately the same points as those of Series $\mathrm{C}$, during clear and almost perfectly calm weather. Two liters of each sample were filtered thru fine bolting cloth. This allowed the diatoms 
and some of the algae to pass thru but retained all the crustaceans and rotifers. This was determined by examination of the filtrate. No chemical analysis was made and the plants were not counterl. The results are shown in Table XV.

Table XV. Showing results of analyses of samples of Series $\mathrm{H}$.

\begin{tabular}{|c|c|c|c|c|c|c|c|c|c|}
\hline \multirow[t]{2}{*}{ Point. . . . } & \multicolumn{2}{|r|}{1} & \multicolumn{2}{|r|}{2} & \multicolumn{2}{|r|}{3} & \multicolumn{2}{|r|}{4} & \\
\hline & 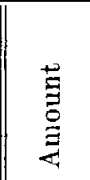 & 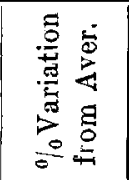 & $\begin{array}{l}\stackrel{+}{\Xi} \\
\stackrel{\Xi}{0} \\
\stackrel{3}{Z}\end{array}$ & 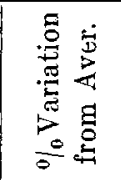 & 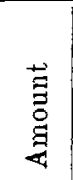 & 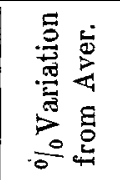 & $\begin{array}{l}\vec{\Xi} \\
\stackrel{\Xi}{\Xi} \\
\text { 眾 }\end{array}$ & 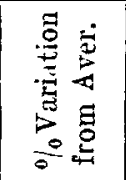 & 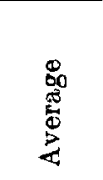 \\
\hline Depth & 4.5 & -11.7 & 5.1 & 0 & 53 & $-1-3.9$ & 55 & t- $7: 8$ & 5.1 \\
\hline Temperature & 94 & -i- 3.3 & 9.0 & 1.1 & 9.0 & $+\quad 1.1$ & 90 & $+\quad 1.1$ & 9.1 \\
\hline B. satanicus. & 600.0 & +2223 & 380 & 795 & 640 & $+65 . \dot{6}$ & 430 & +76.8 & 186.0 \\
\hline Cyclops & 20 & -46.4 & 8.0 & $-i-114.6$ & 3.0 & +20.0 & 20 & +46.7 & $3.7 \check{a}$ \\
\hline Diaptomus & 0 & --100.0 & 40 & - 48.3 & 27.0 & +248.4 & 0 & +1000 & 7.75 \\
\hline Pedalion & 80 & -38.7 & 220 & -692 & 60 & $\begin{array}{l}+538 \\
+\quad 5\end{array}$ & 16,0 & +23.1 & 13.0 \\
\hline Moina & 124.0 & +1296 & 23.0 & 574 & 470 & +12.9 & 22.0 & $\begin{array}{l}+59.3 \\
\end{array}$ & 54.0 \\
\hline
\end{tabular}

At point 1 where the depth is the least the temperature is about one half degree higher than at the other points. At this point, alsi, Brachionus satunicus and Moina, the most abundant animals, are present in great numbers. Whether this "swarm" was caused by the slight difference in depth or temperature one cannot say, but it is probably only a coincidence since farther on, where the wather was deeper, another swarm of Moina was noticed. The averages are given in the following table:

Table XVI. Percent of variation from average of Series H.

\begin{tabular}{|c|c|c|c|c|}
\hline & Mean & Maximum & Minimum & Range \\
\hline B. satanicus . & +111.0 & +222.3 & 79.5 & 301.8 \\
\hline Pedalion & +46.1 & +692 & 538 & 122.0 \\
\hline Moina . & +64.8 & +129.6 & 59.3 & 188.9 \\
\hline Cyclops & $+\quad 570$ & $\begin{array}{r}+1146 \\
+\end{array}$ & 46.7 & 161.3 \\
\hline Diaptomu . . . . . . . & +124.2 & +248.4 & 100.0 & 348.4 \\
\hline
\end{tabular}

The distribution of the two sexes of Moina in this series is inter-

1) See Wipple, "The Microscopy of Dinking Water". 1914, pp. 28 et sey. 
usting. On the whole the females are in the majority except at point 1 where the males are about twice as many. At the point immediately preceding, where a considerable number of Moina is found, the males are totally absent. The following is the detailed distribution:

\begin{tabular}{cccccc} 
Sample & 1 & \multicolumn{2}{c}{0 Males } & 124 & Females \\
. & 2 & 15 &. & 8 & $"$ \\
$"$ & 3 & 5 &. & 42 & $"$ \\
$"$ & 4 & 2 &. & 20 &
\end{tabular}

\section{Discussion of results.}

As far as one can tell from the results the total amount of plankton seems to have a quite uniform distribution, except in a few cases where most of the organisms occur in large or small numbers in a certain place or at a certain time. No correlation is shown between the animals and the plant and chemical constituents. Without further investigation it cannot be said, however, that plankton animals are not in any way affected by the amount of phytoplankton or dissolved chemicals, since the variation for the plants or chemicals might be due mainly to experimental error. It is quite certain that if there are variations in distribution of these constituents they are small and not likely to cause movements of the plankton animals. The depth and temperature are always nearly constant for the whole series and the small variations that oscur do not have any effect upon the distribution of the plankton.

All of the plankton species show an uneven distribution in all cases even where the individuals of a certain species are very numerous. Table XVII gives a summary of the variation of the individual species. The figures are obtained by taking the average of the mean variation and of the range of variation from the average of all the series in which the particular species is present. The table shows that the crustaceans have the least uniform horizontal distribution, the average variation for the three species and the Nauplii being $56 \%$. For the four species of rotilers the average is $50^{\circ}{ }_{10}$, and that of the plants is about $30 \%$. As has

1) The chemical analyses: were made hy lor. Fred H. Heath of the University of North Dakotia. 
'Table XVII.

A verage value or "Percent of variation from average" of all the series.

\begin{tabular}{|c|c|c|c|}
\hline & \multirow{2}{*}{$\begin{array}{c}\text { No. of series } \\
\text { averaged }\end{array}$} & \multicolumn{2}{|c|}{ Averages in percent } \\
\hline & & Mean & Range \\
\hline Amorphous , . . . . . & 4 & +21.4 & 63.5 \\
\hline Micrococcus ...... & 4 & +14.0 & 44.4 \\
\hline Nodularia . . . . . . & $\overline{5}$ & \pm 29.8 & 93.5 \\
\hline Other Algae . . . . . & 5 & -22.1 & 70.2 \\
\hline Diatoms . . . . . . & 3 & \pm 41.8 & 132.1 \\
\hline B. satanicus . . . . . & 7 & +59.0 & 176.3 \\
\hline B. mulleri ..... & 3 & +37.3 & 130.4 \\
\hline Pedalion . . . . . . . & 7 & +46.2 & 133.7 \\
\hline Asplanchma . . . . . & 1 & \pm 57.5 & 218.7 \\
\hline Moina .......... & 2 & \pm 04.0 & 242.7 \\
\hline Cyclops .... & 6 & $\bar{F}_{-} 47.4$ & 139.2 \\
\hline Diaptomus. . . & 4 & +62.7 & 193.3 \\
\hline Nauplii . & 6 & +50.7 & 154.4 \\
\hline
\end{tabular}

been stated before the experimental error in the case of the plants and of the amorphous matter is probably large and may account for a greater part, or all, of the 'variation found. For the crustaceans and rotifers the experimental errors is much smaller, owing to the large portion of the sample that was counted, and the variation found is due almost entirely to the uneven distribution. It is not probable that the small number of individuals that are sometimes found causes the variations to appear large since in Series $\mathbf{H}$ where some of the species are very numerous the variations are above the average.

Direct observations were also made by examining the water surface for aggregates of animals. Duing the summer of 1915, before Moina appeared, crustaceans were frequently not seen for large areas but when they occurred there were usually several together. On two occassions im August and September Moinas were seen in the free water a few meters from the shore, so numerous that they could be seen from a distance of several meters. These "swarms" covered an area of about one half to one meter in diameter while the sur-

1) Ibid. p. 42.

4) Ibid. p. 41 . 
rounding water was almost free from crustaceans. Also when Series $\mathrm{H}$ was collected two aggregates of crustaceans, chiefly Moina, were noticed in the center of Creel Bay. Here, however, the areas were larger than, and not as distinct as those near the shore.

\section{Comparison of the results with those obtained by other investigators.}

In every case that I know of the collections for the study of the horizontal distribution of plankton have been made with a plankton net and, with but few exceptions, concern only the total amount of plankton. The results usually show a small variation but tell nothing about the distribution of the individual species. As far as one can tell from the data for Devils Lake the distribution of the plankton as a whole in that lake seems to be similar to the distribution elsewhere.

A stully of the subject was made on Lake St. Clair, Michigan, by Reighard in $1893^{1} \%$. He collected fourteen series, each ccnsisting of two (in one case three) successive hauls made in the same place. The volume of plankton per square meter of surface was then determined and the average amount of each series computed. In figuring the percentages of variation of the different catches from the average Reighard used the volume of each catch as a basis, while I used the average of the series as a basis. In order to make the results comparable I have applied the latter method to Reighard's data. For all the series, except one, the plus and minus variations and consequently alsu the mean variation, are the same since there are ouly two collections. Table XVIII gives the plus or minus variation for each series and the arerage for all the series (tee p. 299).

In figuring the results by Reighard's method the variations of Series II of the above table become $+23.1 \%$ and $-431 \%$. The last variation is much greater than any other and Reighard states that it "is, possibly, sufficient to be referable to a "swarm".

Similarly Apstein ${ }^{2}$ ) studied the distribution in some of the German lakes collecting thirty-one series, each of from two to five hauls.

\footnotetext{
1) Reiglisd, "A Biological Examination of Lake St. Mlair". Bulletin of the Michigan Fish Commission, No. 4, 1894.

2) Apstein. "Das SüBwasserplankton, Methode und Resultate der quantitativen Untersuchung ". 1896, pp. 51 et seq.
} 
Table XVIII. Rosults obtained from Reighardt's data.

\begin{tabular}{|c|c|c|c|c|c|c|c|}
\hline Series & S II & Variation & from & average & in & percent & \pm 30.1 \\
\hline$"$ & III & $n$ & $n$ & $"$ & $n$ & $n$ & +17.0 \\
\hline r. & IV & , & .. & , & 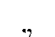 & .. & 0 \\
\hline. & $\mathrm{V}$ & $n$ & .. & 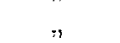 & $n$ & $\because$ & \pm 13.9 \\
\hline$n$ & VI & $"$ & , & , & 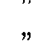 & .. & \pm 14.6 \\
\hline 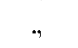 & VII & $"$ & $"$ & , & . & $"$ & 0 \\
\hline r & VIII & $n$ & $n$ &.. &, & .. & \pm 5.4 \\
\hline , & IX & . & $"$ & $"$ & $n$. & .. & +3.1 \\
\hline ", & $\mathrm{X}$ & .. & $n$ & " & 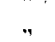 & .. & 0 \\
\hline ", & XIII & $"$ & , &. & 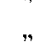 & .. & +9.5 \\
\hline$r$ & XIV & $"$ & $"$ & $"$ &. & , & +4.3 \\
\hline & $X V$ & ,. & .. & ” & $\because$ & .4 & $\pm 1 \pm 7$ \\
\hline & XVI & $n$ & , &, & .. &. & \pm 10.3 \\
\hline & XVIII & $n$ & $n$ & 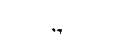 & .. & .. & +8.4 \\
\hline Avera & age $v$ & alue for & the & ries & $"$ & .. & +9.4 \\
\hline
\end{tabular}

All the $c$ itches of a series were taken from equal depths from dilferent parts of a lake. The catches (eighty in all) were undoubtedly all obtained from the pelagic zone at equal depths, but it is probable that the depth of the lake differed at the difforent stations. The mean variation from the average of all the series is found to be $5.5 \%$, corresponding to $9.4 \%$ for Reighard's results. The highest variation found by Apstein is +. $22.8 \%$.

Apstein also counted the different species for three series (one of three and two of two catches) and reports some duta published by Zarharias in 1895. From Apstein's data I computed the percentages for Diaptomus and Cyclops of two of the series, the catches of the third being made in widely different parts of the lake. The following tables give the results of Apstein's counts.

'lable XIX. Results obtained from Apstıin's data for Dobersdorfer See.

\begin{tabular}{|c|c|c|c|c|c|c|c|}
\hline & \multicolumn{2}{|c|}{ No. $27 \mathrm{a}$} & \multicolumn{2}{|c|}{ No. $27 \mathrm{e}$} & \multicolumn{2}{|c|}{ No. $27 \mathrm{c}$} & \multirow[b]{2}{*}{ Average } \\
\hline & $\begin{array}{l}\text { Nımber } \\
\text { per } m^{3}\end{array}$ & $\begin{array}{l}\% \text { Var. } \\
\text { fr. Av. }\end{array}$ & $\begin{array}{l}\text { Number } \\
\text { per } m^{3}\end{array}$ & $\begin{array}{l}\% \text { Vir. } \\
\text { fr. Av. }\end{array}$ & $\begin{array}{l}\text { Number } \\
\text { per } \mathrm{m}^{\mathbf{3}}\end{array}$ & $\begin{array}{l}\text { \% Var. } \\
\text { fr. Av. }\end{array}$ & \\
\hline Cycl & 122088 & +6.7 & 93.021 & -18.6 & 128016 & +11.9 & 114.377 \\
\hline Diaptom. & 323.320 & -7.6 & 198.208 & --442 & 539.947 & 151.8 & 3 อ̄5 492 \\
\hline
\end{tabular}

In Dobersdorfer See the Cyclops show an average mean variation of $\pm 12.4 \%$ and a range of $30.5 \%$. For Diaptomus the figures are +345 and $96.0 \%$. In the case of Gr. Plöner See the variation for each catch and mean variation are the same since there are only 
Table XX. Results obtained from Apstein's data for Gr. Plöner See.

\begin{tabular}{l||c|c|c|c|c}
\hline & \multicolumn{2}{c|}{ No. 71 a } & \multicolumn{2}{c|}{ No. 71e } & \\
\cline { 2 - 6 } & $\begin{array}{c}\text { Number } \\
\text { pr catch }\end{array}$ & $\begin{array}{c}\% \text { Variation } \\
\text { from Aver. }\end{array}$ & $\begin{array}{c}\text { Number } \\
\text { pr catch }\end{array}$ & $\begin{array}{c}\text { \% Variation } \\
\text { from Aver. }\end{array}$ & Average \\
\hline \hline Cyclops ... & 887 & -1.5 & 915 & +1.5 & 901.0 \\
Diaptomus . & 26 & -13.3 & 34 & +13.3 & 30.0 \\
Nauplii ... & 372 & -13.1 & 286 & -13.1 & 329.0
\end{tabular}

two series. The percentages are much lower than those for Dobersdorfer See.

For one series Zacharias made three catches within a distance of 600 meters. In these he counted one plant and tbree animal species. These are the results for the animals:

Table XXI. Results obtained from Zacharias' data.

\begin{tabular}{|c|c|c|c|c|c|c|c|}
\hline & \multicolumn{2}{|c|}{ SehluBgarten } & \multicolumn{2}{|c|}{ Aleshorg } & \multicolumn{2}{|c|}{ Rott's Gärten } & \multirow[b]{2}{*}{ Average } \\
\hline & Number & $\begin{array}{l}\% \text { Var. } \\
\text { fr Av. }\end{array}$ & Number & $\begin{array}{l}\% \text { Var. } \\
\text { fr. Av. }\end{array}$ & Number & $\begin{array}{l}\text { \% Var. } \\
\text { tr. Av. }\end{array}$ & \\
\hline Hyalodaphnia & 630 & +10.5 & 540 & --. 5.2 & 540 & -52 & 570.0 \\
\hline Copepoda & 720 & -8.8 & 840 & +6.3 & 810 & +25 & 790.0 \\
\hline Bosm. coregoni & 150 & 0 & 150 & 0 & 150 & 0 & 150.0 \\
\hline
\end{tabular}

Hyalodaphnia has a mean variation of $\pm 7.0 \%$ and a range of $15.7 \%$, and the copepods a mean of $\pm 5.9 \%$ and a range of $15.1 \%$. These figures as well as those of Apstein are much lower than the Devils Lake results, and correspond more nearly with those obtained by Reighard and by Apstein for the total amount of plankton.

Kofoid ${ }^{1}$ ) tested the longitudinal distribution of plankton in Illinois River by making "a series of ten catches in immediäte succession from a boat anchored in mid-channel". The current was flowing at the rate of nearly two miles an hour, and the lime required for collecting was about two hours. The catches therefore represent plankton taken from a body of water about three miles in length. From the centrifuged material the volume of plankton per cubic meter was computed and the following percentages were obtained:

1) Kofoid, "The Plankton of the Illinois River". Bulletin of the Illinois State Laboratory of Natural History, 1903, pp. 269 et seq. 
Table XXII. Percentages of variation obtained by Kofoid.

\begin{tabular}{|c|c|c|c|c|c|}
\hline Mean & variation & from & the & avernge & $+8.6 \%$ \\
\hline Maximum & 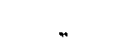 & 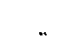 & 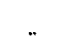 & -8 & - $86 \%$ \\
\hline Minimum & " & .. & .. & " & $5.5 \%$ \\
\hline Range of & $"$ & 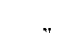 & $"$ & " & $14.1 \%$ \\
\hline
\end{tabular}

Kofoid's results thus show a smaller variation than those of Reighard and of Apstein, but cannot very well be compared to samples obtained from a lake, especially during calm weather.

"Swarms" or aggregates, similar to those seen in Devils Lake, have been reported several timcs by different investigators, e. g. by Huitfeldt-Kaas ${ }^{1}$ ) and Ward $\left.^{2}\right)$. The aggregates have usually consisted of Cladocera and in most cases they have been observed near the shore, but occasionally in the free water. No great consideration is given them, however, since they are supposed to occur but seldom and therefore do not greatly affect the results of quantitative plankton studies. The comparatively irregular distribution shown by the zooplankton in Devils Lake is in all probability very constant, since about the same results were obtained for all the series. Probably the large variation shown by the plants and the amorphous matter is to a large extent due to experimental error. If the supposition that the phytoplankton is uniformly distributed is correct my work shows that the experimental error for the Sedgwick-Rafter method is about $30 \%$. The method as described by Whipple was closely followed both as to procedure and amounts filtered and counted. It is probable that the ersors could have been reduced somewhat by counting a larger number of cells, but usually the organisms were well distributed over the cells so that the amounts of the most abundant plants agreed quite closely for the different squares.

The methods used for the animals, on the other hand, were quite thoro and no large error is possible. It is hardly conceiveable that the organisms in Devils Lake should have a more irregular distribution than those elsewhere, but since I can find but few data that show the distribution of species in other lakes, no definite comparisons can be made. Apstein's and Zacharias' results for the counts of the individual species show a distribution very similar to that

") Huitleldt-Kaas, „Das Plankton in norwegischen Binnenseen". Biol. Centralblatt, 1898, Bd. XVIII, S. 625 et seq.

2) Ward, "A Biological Lxamination of Lake Michigan". Bulletin of the Michigan Fish Commission, No. 6, 1896, pp. 63-64. 
usually found for the total amount of plankton ${ }^{1}$ ). Their catches were made with a net and represent the number of individuals in a vertical column of water. It is possible that the vertical distribution for the different catches differed altho the total amount for

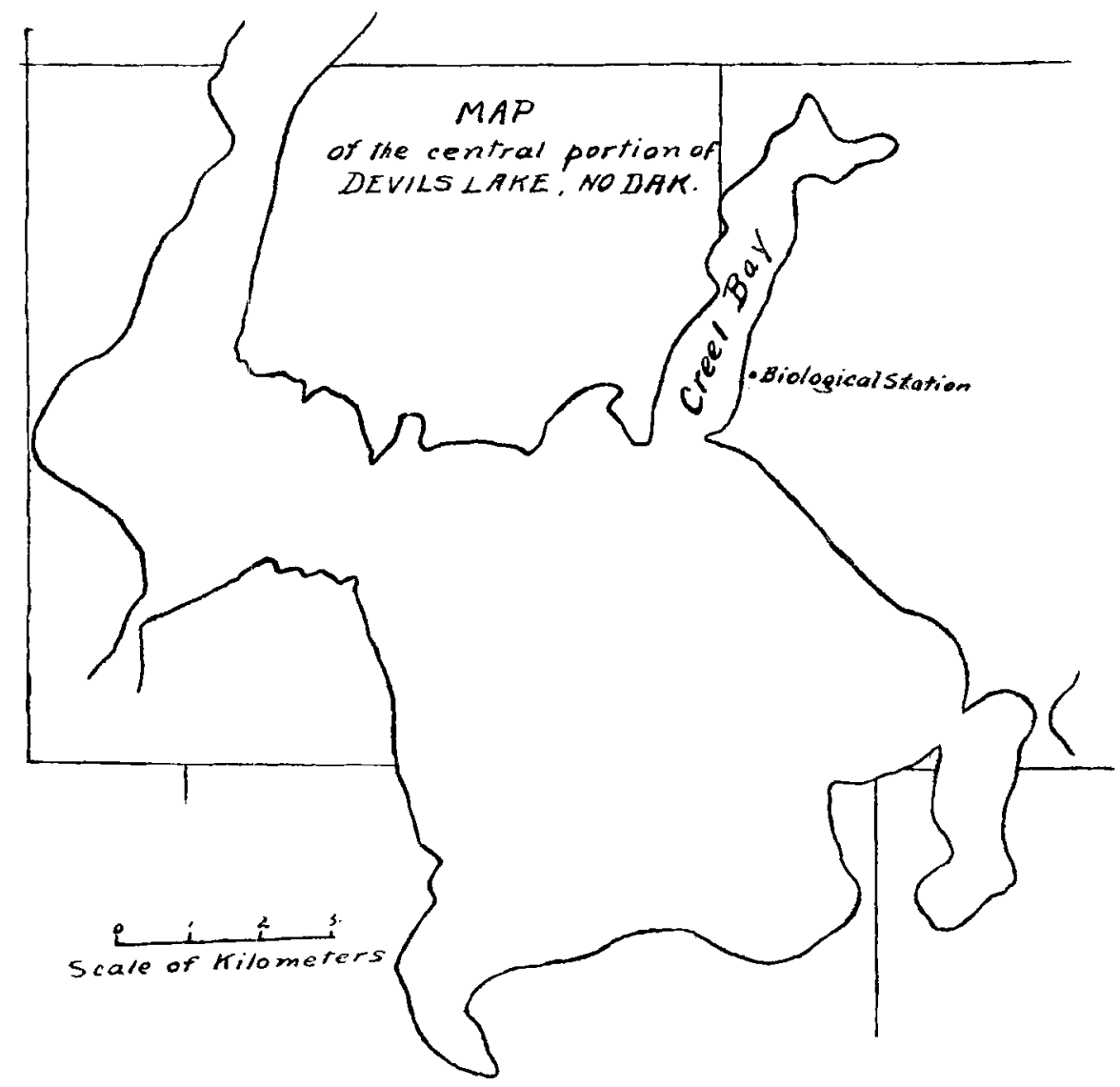

Fig. 1.

the entire column differed but slightly from that of another column. If this were the case the horizontal distribution for the different levels would differ. The cullections made in Devils Lake to test the

1) In the case of Cyclops and Diaptomus for Dobersdorfer See Apstein finds a somewhat larger variation, the mean for Cyclops being $\pm 12.4 \%$ and for Diaptomus $34.5 \%$. For Diaptomu; the maximum is $+51.8 \%$ and the minimum - $44.2 \%$, making a range of $96 \%$. 


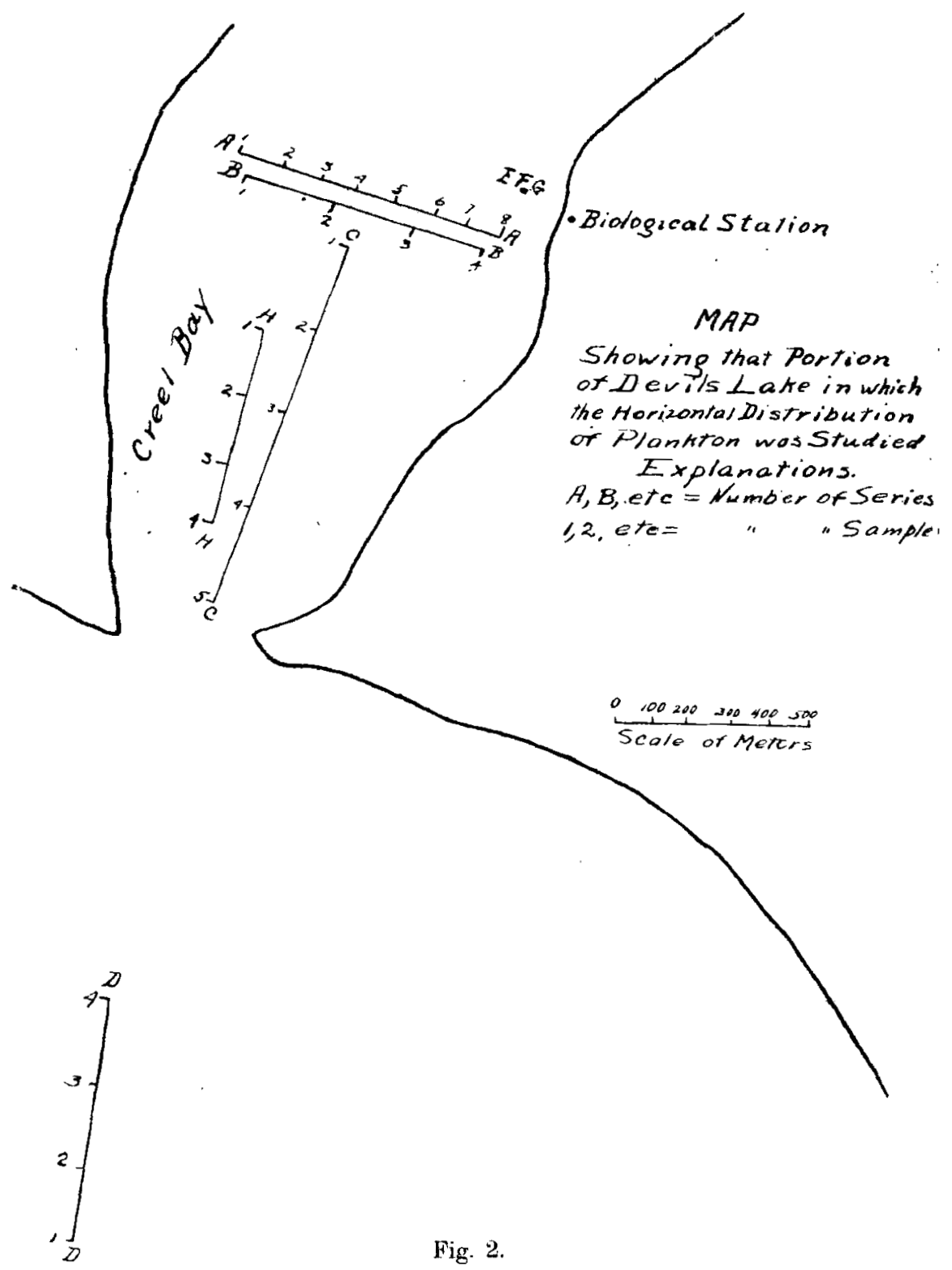

vertical distribution (see Table l) show a large difference in number of animals of a column of water between two periods of collecting. Moreover when a large volume of water is obtained, whether with 
304 E. G. Moberg, Horizontal Distribution of the Zooplankton in Devils Lake etc.

a net or a pump, the differences in distribution tend to be reduced, since by this method several thickly populated portions of water may be included while, on the other hand the small sample usually collected for filtration in the Sedgwick-Rafter method may be obtained either entirely from one of these portions or between them, from the water containing but few individuals. The Sedgwick-Rafter method would, therefore. be more precise for studying loeal distribution of the plankton species.

Neither can the distribution of the total amount of plankton in Devils Lake be compared to that in other lakes, since my results concern the individual species only. In the majority of cases it appears, however, that some species make up in volume or weight for the deficiency caused by others. Also when the animals are few in number they do not appreciably affect the total amount of plankton.

\section{Conclusions.}

From the results obtained by the study of the horizontal distribution of the planktonts in Devils Lake the following may be concluded:

1) The zooplanktonts in Devils Lake show a greater irregularity in horizontal distribution than has been found elsewhere for the total amount of plankton or for the individual species in the few cases where they have been studied.

2) The phytoplanktonts show a more regular distribution, but the variations found are probably too large owing to the difficulty of obtaining a satisfactory method for studying their distribution.

3) No eorrelation is shown between the zooplanktonts, the phytoplanktonts, and the chemical and physical conditions. 